\title{
Patentability of Stem Cells in the United States
}

\author{
Sarah E. Fendrick and Donald L. Zuhn, Jr. \\ McDonnell Boehnen Hulbert \& Berghoff, LLP, Chicago, Illinois 60606-6709 \\ Correspondence: zuhn@mbhb.com
}

\begin{abstract}
Until recently, the patentability of stem cells was well established within the judicial and statutory framework in the United States. However, the shifting landscape of patent law, particularly with regard to patent-eligible subject matter under 35 U.S.C. §101, presents new challenges to the patentability of stem cells. In this paper, we discuss the legal precedent that paved the way for stem cell patents, including Diamond v. Chakrabarty and In re Bergy. Additionally, we review recent Supreme Court cases and recent guidance issued by the U.S. Patent and Trademark Office that impose new limitations on patent-eligible subject matter and thereby threaten the patentability of stem cells in the United States.
\end{abstract}

\section{STATUTORY FRAMEWORK FOR STEM CELL PATENTABILITY}

35 U.S.C. $\$ 101$ sets out the subject matter that is patent-eligible. Section 101 reads as follows:

Whoever invents or discovers any new and useful process, machine, manufacture, or composition of matter, or any new and useful improvement thereof, may obtain a patent therefor, subject to the conditions and requirements of this title.

The Supreme Court has identified three exceptions to $\$ 101$ 's broad patent-eligibility principles: laws of nature, physical phenomena, and abstract ideas (Diamond v. Diehr (450 U.S. 175) (1981)). However, no specific statutory exemptions exist for the patentability of stem cells. The closest that legislation has come to addressing the patentability of stem cells is in the LeahySmith America Invents Act (AIA), Pub. L. 11229, sec. 33(a), 125 Stat. 284, which states:

Notwithstanding any other provision of law, no patent may issue on a claim directed to or encompassing a human organism.
The legislative history of the AIA further includes the following statement, which speaks directly to the applicability of this provision to stem cells:

[T] he U.S. Patent Office has already issued patents on genes, stem cells, animals with human genes, and a host of non-biologic products used by humans, but it has not issued patents on claims directed to human organisms, including human embryos and fetuses. My amendment would not affect the former, but would simply affirm the latter. ${ }^{1}$

Based on this passage, stem cells are specifically identified as not falling within the exemption of $\$ 101$ patent-eligible subject matter, and in fact it reinforces that stem cells are recognized as patent-eligible subject matter.

\footnotetext{
${ }^{1} 157$ Cong. Rec. E1177-04 (testimony of Representative Dave Weldon previously presented in connection with the Consolidated Appropriations Act, 2004, Pub. L. 108-199, 634, 118 Stat. 3, 101, and later resubmitted with regard to the AIA; see 149 Cong. Rec. E2417-01) (emphasis added).
}

Editors: Salim Mamajiwalla and Rochelle Seide

Additional Perspectives on Intellectual Property in Molecular Medicine available at www.perspectivesinmedicine.org

Copyright (C) 2015 Cold Spring Harbor Laboratory Press; all rights reserved; doi: 10.1101/cshperspect.a020958

Cite this article as Cold Spring Harb Perspect Med 2015;5:a020958 
S.E. Fendrick and D.L. Zuhn, Jr.

\section{THE CHANGING LANDSCAPE OF PATENTABLE SUBJECT MATTER}

The pivotal point in patent protection for the biotechnology industry was the Supreme Court's decision rendered in Diamond v. Chakrabarty, wherein the Court held for the first time that living matter constituted patentable subject matter if created by the hand of man ((447 U.S. 303) (1980)). The patented invention in Chakrabarty was a genetically engineered Pseudomonas aeruginosa bacterium capable of metabolizing components of crude oil by expression of two stable energy-generating plasmids. In a 5-4 decision, the Court reasoned that the bacterium was patent-eligible because it had markedly different characteristics from any bacterium found in nature. The importance of the decision came in the Court's reasoning that "anything under the sun made by man" would be patent-eligible and the broad directive of the decision to remove restrictions on subject matter eligibility (Chakrabarty (447 U.S. at 309)).

The important companion case to Chakrabarty is In re Bergy, which provides additional guidance regarding the types of natural products that are patent-eligible under $\$ 101$ ((596 F.2d 952) (1979)). The claims at issue in In re Bergy were directed to a "biologically pure culture" of the microorganism Streptomyces vellosus, which were initially rejected by the patent examiner as being directed to a product of nature. The U.S. Patent and Trademark Office (USPTO) Board of Appeals upheld the examiner's rejection based on the single basis that the claim covered a living organism. On appeal, the United States Court of Customs and Patent Appeals (CCPA) reversed on the grounds that the biologically pure culture was not a product of nature and that patentability was not affected by the microorganism being alive. Similar to Chakrabarty, the CCPA's decision opened the door for patent protection for inventions within the biotech industry.

Following the legal framework set by Chakrabarty and In re Bergy, stem cells were found to be patentable subject matter, with the USPTO issuing a wide range of stem cell patents. The first stem cell patents were directed to hema- topoietic stem cells (e.g., U.S. Patent Nos. 5,436,151 and 5,670,147), fetal/neonatal cells (e.g., U.S. Patent No. 5,004,681), and mesenchymal cells (e.g., U.S. Patent No. 5,827,740). Embryonic stem cells were first patented from animals (e.g., birds [U.S. Patent Nos. 5,340,740 and 5,656,479] and mice [U.S. Patent Nos. $5,453,357$ and 5,985,659]). The first human embryonic stem cell patents were U.S. Patent Nos. $5,843,780,6,200,806$, and 7,029,913 issued to James Thomson from the University of Wisconsin. Since these patents were issued, more than 1000 patents claiming stem cells have been issued in the United States.

However, over the past 2 years, the landscape for life sciences and biotechnology patent law has undergone significant change. Of particular importance are the Supreme Court's decisions rendered in Mayo Collaborative Services v. Prometheus Laboratories, Inc. (132 S. Ct. 1289) (2012) and Association for Molecular Pathology v. Myriad Genetics, Inc. (133 S. Ct. 2107) (2013), in which the Supreme Court further defined the bounds of patent-eligible subject matter under 35 U.S.C. \$101.

In the Mayo case, the Court unanimously held that claims directed to the relationship between the concentrations of blood metabolites and response to a therapeutic drug were unpatentable, stating that they "effectively claim the underlying laws of nature themselves" (Mayo Collaborative Services (132 S. Ct. at 1296)). The patents at issue generally claimed methods reciting the steps of (1) administering a thiopurine drug to a subject and (2) determining the levels of the drug or the drug's metabolites in red blood cells in the subject. The measured metabolite levels are then compared to predetermined metabolite levels, wherein measured metabolite levels in the patient that are outside the predetermined range indicate a need to increase or decrease the level of drug to be administered so as to minimize toxicity and maximize treatment efficacy.

In arriving at its decision, the Court inquired whether the claims did more than merely recite laws of nature. The Court found that a claim that encompasses the use of a natural law must also include additional "elements, sometimes refer- 
red to as an 'inventive concept,' sufficient to ensure that the patent ... amounts to significantly more than a patent upon the natural law itself" (Id. at 1294 (emphasis added)). Under the Mayo framework, if steps in a claimed process involve well-understood, routine, conventional activity previously engaged in by researchers in the field, such claims likely encompass nonpatentable subject matter. This decision was the first to restrict the once expansive boundaries of patent-eligible subject matter under $\$ 101$.

In May 2013 the bounds of patent-eligible subject matter under $\$ 101$ were further confined in the Supreme Court's Myriad decision, which held that a naturally occurring DNA segment is a product of nature and not patent-eligible merely because it had been isolated. The Court reasoned that "separating [a] gene from its surrounding genetic material is not an act of invention" (Myriad Genetics, Inc. (133 S. Ct. at 2117) (2013)). The Court, however, also determined that "cDNA does not present the same obstacles to patentability as naturally occurring, isolated DNA segments" (Id. at 2119). In particular, the Court explained that "cDNA retains the naturally occurring exons of DNA, but it is distinct from the DNA from which it was derived," and therefore, "cDNA is not a 'product of nature' and is patent eligible under $\$ 101$ ” (Id.). However, the Court also explained that very short series of DNA that do not have intervening introns to remove when creating cDNA may be indistinguishable from natural DNA and thus unpatentable.

The total impact of the Mayo and Myriad decisions remains uncertain because the Court left open the application of its rulings to other technologies beyond diagnostic methods and DNA. However, based on the USPTO's recently issued guidance on patent-eligible subject matter under $\$ 101$, the impact of these decisions appears to be significant.

\section{USPTO GUIDANCE ON SUBJECT MATTER ELIGIBILITY}

In response to the Supreme Court's decisions in Mayo and Myriad, the USPTO issued a memorandum on March 4, 2014, entitled "Guidance for Determining Subject Matter Eligibility of Claims Reciting or Involving Laws of Nature, Natural Phenomena, \& Natural Products" (or Myriad-Mayo Guidance). The Myriad-Mayo Guidance implements a new procedure to be used by patent examiners to assess whether claims in patent applications recite patent-eligible subject matter under 35 U.S.C. $\$ 101$. The new examination procedure set forth in the Myriad-Mayo Guidance is to be applied such that "all claims (i.e., machine, composition, manufacture, and process claims) reciting or involving laws of nature/natural principles, natural phenomena, and/or natural products should be examined using the Guidance" (Myriad-Mayo Guidance, p. 1 [emphasis in Guidance]). The new examination procedure involves a three-step analysis in which examiners are required to make the following inquiries: (1) Is the claimed invention directed to one of the four statutory patent-eligible subject matter categories: process, machine, manufacture, or composition of matter? (2) Does the claim recite or involve one or more judicial exceptions identified by the Supreme Court in Diehr (i.e., laws of nature, physical phenomena, or abstract ideas)? (3) Does the claim as a whole recite something significantly different than the judicial exceptions?

Although Mayo and Myriad concerned patents directed to diagnostic methods and isolated nucleic acid molecules, the Myriad-Mayo Guidance goes far beyond the holdings of these decisions to encompass a wide array of subject matter. With respect to the Myriad decision, the Myriad-Mayo Guidance states that "while the holding in Myriad was limited to nucleic acids, Myriad is a reminder that claims reciting or involving natural products should be examined for a marked difference under Chakrabarty" (Id.). In fact, the Myriad-Mayo Guidance states that its new examination procedure applies to:

chemicals derived from natural sources (e.g., antibiotics, fats, oils, petroleum derivatives, resins, toxins, etc.); foods (e.g., fruits, grains, meats and vegetables); metals and metallic compounds that exist in nature; minerals; natural materials (e.g., rocks, sands, soils); nucleic acids; organisms (e.g., bacteria, plants, and multicellular an- 
S.E. Fendrick and D.L. Zuhn, Jr.

imals); proteins and peptides; and other substances found in or derived from nature ( $I d$. at 2).

Although the Myriad-Mayo Guidance specifically lists "organisms (e.g., bacteria, plants, and multicellular animals)," it does not specifically identify stem cells as falling within the scope of the Myriad-Mayo Guidance. However, based on the breadth of the Guidance, stem cells will be examined pursuant to the new examination procedure set forth in the Guidance.

Pursuant to the Myriad-Mayo Guidance, examiners are to answer the third inquiry (i.e., whether a claim recites something significantly different than a judicial exception) by analyzing the claim in view of 12 factors. The most relevant of the 12 factors to the patent eligibility of stem cells are those factors concerning composition (or product) claims. Specifically, factors (a) and (g) can be used by examiners to assess the patent eligibility of product claims, and in particular claims directed to stem cells:

(a) Claim is a product claim reciting something that initially appears to be a natural product, but after analysis is determined to be non-naturally occurring and markedly different in structure from naturally occurring products.

(g) Claim is a product claim reciting something that appears to be a natural product that is not markedly different in structure from naturally occurring products [Id. at 4 (emphasis added)].

The Myriad-Mayo Guidance provides further insight as to what constitutes "markedly different in structure" by specifying that the mere isolation of a nucleic acid molecule from a cell does not yield a molecule having a markedly different structure as compared with the naturally occurring nucleic acid molecule.

Although the Myriad-Mayo Guidance also sets out a number of specific examples to illustrate the types of subject matter that would be found to be patent-eligible, none of the examples concerns stem cells. Thus, there is currently some uncertainty as to how examiners will apply the new examination procedure set forth in the Myriad-Mayo Guidance to stem cells. Nevertheless, patent applicants should proceed (for the time being) under the assumption that an "isolated" stem cell will not be found to be "sig- nificantly different" from naturally occurring stem cells unless the stem cell can be shown to be structurally different from a naturally occurring product.

Although the future of stem cell patentability - as well as the patentability of a wide array of biotechnological subject matter-is currently on unstable ground, many applicants and practitioners are holding out hope that the USPTO will revise or supplement the Myriad-Mayo Guidance. This expectation is based on the USPTO's response to feedback received from applicants and practitioners following the issuance of the Myriad-Mayo Guidance. In particular, in the months following the issuance of the Guidance, the USPTO was inundated with comments criticizing the new examination procedure outlined in the Myriad-Mayo Guidance. For example, a joint comment submitted by the Biotechnology Industry Organization, the Coalition for 21st Century Medicine, five biotech companies, and six individuals asserted that "[i]n framing the March Guidance, the USPTO seems to have focused only on selected Supreme Court cases and has not drawn on all available precedent," and further contended that "[a]dditional insight can be gleaned by a closer reading of those Supreme Court cases on which the USPTO has focused" (BIO Supplemental Comments, October 14, 2014, pp. 2-3).

In response to the critical feedback it received, the USPTO announced that it would be issuing revised guidance. ${ }^{2}$ In addition, the USPTO has discussed aspects of the MyriadMayo Guidance that applicants and practitioners can expect to change and aspects that applicants and practitioners can expect to remain the same. With respect to the latter, the USPTO has indicated that any revised guidance will not be limited to the specific subject matter at issue in Myriad (i.e., nucleic acid molecules) and will instead apply to claims directed to any natural product. Thus, as the Myriad-Mayo Guidance applies to stem cell claims, the revised guidance can be expected to apply to stem cell claims.

\footnotetext{
${ }^{2}$ At the time of publication of this article, the USPTO had not issued revised guidance.
} 
Among the possible revisions to the Myriad-Mayo Guidance, the USPTO has suggested that any revised guidance will permit applicants to establish that the subject matter recited in a product claim is significantly (or markedly) different from a natural product by showing that the claimed subject matter is functionally different from the natural product. Such a change could impact the patent eligibility of stem cells, as it would permit patent applicants to present evidence supporting an argument that the subject matter of their claims possesses a different function or utility from the naturally occurring products from which the claimed subject matter was derived. However, whether the USPTO will issue revised guidance and whether such revised guidance will introduce any significant revisions remain open questions for now.

\section{CHALLENGES TO THE PATENTABILITY OF STEM CELLS}

In 2006, the first major challenge to the patentability of stem cells was raised by two public interest groups, New York's Public Patent Foundation and California's Foundation for Taxpayer and Consumer Rights, now known as Consumer Watchdog, which filed requests with the USPTO in the form of reexaminations to revoke three Wisconsin Alumni Research Foundation (WARF) patents covering embryonic stem cells. ${ }^{3}$ The USPTO granted all three requests for reexamination based on a "substantial new question of patentability" and subsequently rejected the claims in each of the involved patents as anticipated and/or obvious. In response to the USPTO's ruling, WARF narrowed the claims of the '806 patent that were directed to the stem cells to only include stem cells derived from preimplantation embryos. WARF also

${ }^{3}$ U.S. Patent Nos. 5,843,780 and 6,200,806 were challenged through an ex parte request for reexamination, and U.S. Patent No. 7,029,913 was challenged by an inter partes request for reexamination. The major difference between these proceedings is that an ex parte reexamination only provides limited participation rights for the requester whereas an inter partes proceeding allows the requester to have participation rights throughout the proceeding, including appeal rights. amended claim 9 directed to methods for producing the stem cells to recite that the cells produced by the method were "capable of proliferation as undifferentiated cells for more than 1 year." The claims of the ' 806 patent were amended in the same manner. The USPTO determined that the amended claims in each of the challenged patents were directed to patentable subject matter and issued reexamination certificates for both patents involved in the ex parte reexaminations. Similarly, the claims of the'913 patent involved in the inter partes reexamination were found to be patentable.

Because the reexaminations of the ' 780 and '806 patents were ex parte reexaminations, the final decisions of the USPTO could not be appealed. However, Consumer Watchdog appealed the inter partes reexamination decision to the United States Court of Appeals for the Federal Circuit (the court that handles all patent-related appeals). Appealing from the Board decision that affirmed the patentability of the '913 patent, Consumer Watchdog argued to the Federal Circuit that the claims of the' 913 patent were invalid because they covered ineligible subject matter and were anticipated and obvious. With respect to its argument that the claims of the ' 913 patent encompassed ineligible subject matter, Consumer Watchdog argued that the '913 patent was invalid under 35 U.S.C. $\$ 101$ because the claimed stem cells fell within the "product of nature" exception to statutory subject matter. In support of this argument, Consumer Watchdog attempted to draw analogies between its appeal and the Myriad case in its opening brief by arguing that like the claims in Myriad, the claims of the '913 patent were drawn to neither a method of preparation nor a scientific application of the claimed composition and that WARF did not create or alter the properties of the claimed stem cells any more than Myriad had created or altered the genetic information encoded in the claimed DNA.

In its responsive brief, the United States argued that Consumer Watchdog lacked standing, and therefore that its appeal should be dismissed. In support of its argument, the government pointed to the lack of a "particularized, real-world consequence” of the USPTO's deci- 
S.E. Fendrick and D.L. Zuhn, Jr.

sion for Consumer Watchdog. The government explained that Consumer Watchdog had no commercial interest in the subject matter of the '913 patent, did not face a plausible risk of an infringement claim, and was not a prospective competitor or licensee of WARF.

On June 4, 2014, the Federal Circuit dismissed Consumer Watchdog's appeal for lack of Article III standing. The court indicated that Consumer Watchdog must establish standing by showing that (1) it had suffered an "injury in fact" that was both concrete and particularized, and actual or imminent (as opposed to conjectural or hypothetical); (2) the injury was fairly traceable to the challenged action; and (3) it was likely, rather than merely speculative, that a favorable judicial decision would redress the injury (Consumer Watchdog v. Wisconsin Alumni Research Foundation (Fed. Cir. 2014)). Although the court indicated that Article III standing is not necessarily a requirement to appear before an administrative agency (such as the USPTO or its Patent Trial and Appeal
Board), standing requirements under the Constitution must be satisfied once a party seeks review in a federal court (such as the Federal Circuit). The Federal Circuit found that Consumer Watchdog had not alleged any injury in fact related to the WARF stem cell patent because it was not engaged in any activity involving human embryonic stem cells that could form the basis for an infringement claim, did not allege that it intended to engage in such activity, and did not allege that it was an actual or prospective licensee or that it had any other connection to the '913 patent or the claimed subject matter. The only alleged injury recognized by the court was the Board's decision upholding the patent, which the court found insufficient to confer standing. In rendering its decision based on standing, however, the Federal Circuit did not opine on the question of stem cell patentability, leaving that issue for another day. As such, the issue of the patentability of stem cells has yet to be addressed in the federal courts. 


\section{$\&_{\mathrm{CSH}}^{\infty} \&$ Cold Spring Harbor

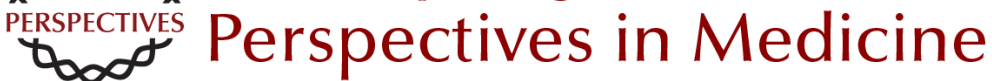

\section{Patentability of Stem Cells in the United States}

Sarah E. Fendrick and Donald L. Zuhn, Jr.

Cold Spring Harb Perspect Med 2015; doi: 10.1101/cshperspect.a020958 originally published online August 20, 2015

\section{Subject Collection Intellectual Property in Molecular Medicine}

Patentability of Stem Cells in the United States Sarah E. Fendrick and Donald L. Zuhn, Jr.

Inventorship and Authorship Antoinette F. Konski and Linda X. Wu

The Patentability of Stem Cells in Australia Jenny Petering and Prue Cowin

Impact of America Invents Act on Biotech Intellectual Property

Amanda Murphy, Michael Stramiello, Jonathan Stroud, et al.

Introduction to Intellectual Property: A U.S.

Perspective

Amanda Murphy, Michael Stramiello, Stacy Lewis, et al.

The Role of Regulatory Agencies and Intellectual Property: Part I

Kevin E. Noonan

Canada's Patented Medicines (Notice of Compliance) Proceedings and Intellectual

Property

Henry Bian and Conor McCourt

Patentability of Genes: A European Union

Perspective

Paul Cole
The Impact of Myriad on the Future Development and Commercialization of DNA-Based Therapies and Diagnostics

Michele Wales and Eddie Cartier

Protecting Traditional Knowledge Related to

Biological Resources: Is Scientific Research

Going to Become More Bureaucratized?

Prashant Reddy and Malathi Lakshmikumaran

Protecting Trade Secrets in Canada

Noel Courage and Janice Calzavara

Inherent Anticipation in the Pharmaceutical and

Biotechnology Industries

Michael Goldman, Georgia Evans and Andrew Zappia

The Role of Regulatory Agencies and Intellectual

Property: Part II

Kevin E. Noonan

Baseball Bats and Chocolate Chip Cookies: The Judicial Treatment of DNA in the Myriad Genetics Litigation lan Binnie and Vanessa Park-Thompson

The Impact of Myriad and Mayo: Will

Advancements in the Biological Sciences $\mathrm{Be}$

Spurred or Disincentivized? (Or Was Biotech

Patenting Not Complicated Enough?) Jennifer Gordon

Trade Secrets in Life Science and Pharmaceutical Companies

Tara Nealey, Ronald M. Daignault and Yu Cai

For additional articles in this collection, see http://perspectivesinmedicine.cshlp.org/cgi/collection/ 